\title{
THE OCCURRENCE OF FOETAL ERYTHROPOIESIS AFTER INFANCY
}

\author{
BY \\ ALAN B. RAPER \\ From the Department of Pathology, United Bristol Hospitals, and the Department of Child Health, \\ University of Bristol
}

(RECEIVED FOR PUBLICATION MAY 23, 1963)

In a previous study the change from foetal to adult erythropoiesis, as reflected in the peripheral blood, was followed up to the age of 32 weeks (Fraser and Raper, 1962). Before that age chemically-estimated foetal haemoglobin ( $\mathrm{Hb}$ F) had reached the adult level, and after that age foetal cells, demonstrated by their partial resistance to an acid buffer, had fallen to less than $1 \%$ of the red cells. An explanation was offered in terms of a progressive maturation of gene-controlled enzyme systems, whereby production of the $\gamma$-polypeptide chains of $\mathrm{Hb} F$ was superseded by that of the $\beta$-chains of adult haemoglobin ( $\mathrm{Hb} \mathrm{A}$ ). But it was recognized that the process was not synchronous in all the erythropoietic cells.

After early infancy, $\mathrm{Hb} \mathrm{F}$ can be found in the blood in a variety of circumstances: (1) In the presence of a clearly inherited abnormality, the 'high-F' gene (Conley, Weatherall, Richardson, Shepard and Charache, 1963): this will not be further considered here, except in comparison with other conditions. (2) In certain anaemias that begin in early infancy. (3) In severe acquired disturbances of haemopoiesis, leukaemia, aplasia, myelosclerosis, and megaloblastic anaemias (Beaven, Ellis and White, 1960). Amongst the anaemias that begin in early infancy, a raised $\mathrm{Hb} \mathrm{F}$ content of the blood is most often found in the haemoglobinopathies, especially those that are caused by an abnormality in the $\beta$-polypeptide chain of the haemoglobin molecule, such as thalassaemia, sickle-cell anaemia, and some of their variants. It is a reasonable hypothesis that $\mathrm{Hb} \mathrm{F}$ appears in these anaemias because they begin concurrently with the normal change from foetal to adult erythropoiesis. Stated in chemical terms the suggestion is that, especially when haemoglobin turnover is greatly increased, the limiting factor is the supply of $\beta$-polypeptide chains, and that the deficit can be made good by a continued use of the $\gamma$-chain pathway; and it must be supposed that this pathway will be more effectively used if it is kept open from infancy onwards, rather than if it is required to open again in adult life (Zuelzer and Robinson, 1961).

Does the synthesis of $\mathrm{Hb} \mathrm{F}$ continue, however, because there is a specific difficulty in making one part of the haemoglobin molecule, which it can replace, or because it is an easier process than the manufacture of $\mathrm{Hb} \mathrm{A}$, whatever the cause of the anaemia? Can the appearance of $\mathrm{Hb}$ in the anaemias of later childhood and adult life be explained by a reversion to foetal erythropoiesis, or is $\mathrm{Hb} \mathrm{F}$ synthesis imposed by some acquired disability in erythropoiesis? There are few severe anaemias that begin at the same time of life as the haemoglobinopathies, and could thus provide a comparison with them; but there are other states which at this time of life may interfere with erythropoiesis, or with protein synthesis.

It was with these questions in mind that a simple investigation was planned with the following objects:

(1) To discover how long in normal children there remained a tendency to produce foetal cells; (2) to discover if possible what factors prolonged or increased this tendency; and (3) amongst the diseases known to favour $\mathrm{Hb} F$ production, to decide whether the tendency was more pronounced soon after early infancy than in adult life.

The method adopted was the examination of blood smears by the technique of Kleihauer, Braun and Betke (1957). It had been shown that foetal cells could still be detected by this sensitive method after the $\mathrm{Hb} F$ of a child's haemolysate had reached the adult level (Fraser and Raper, 1962); and it was expected that the use of this method would be a delicate test of any remaining capacity to produce foetal cells. It is to be noted that the method is competent to detect erythropoiesis of foetal type, and it was so used; but that it will not detect a small 
increase in $\mathrm{Hb} \mathrm{F}$ in the blood if this is evenly distributed amongst all the erythrocytes. Its application, in the event, discovered the presence of foetal erythropoiesis in many other conditions besides the anaemias.

\section{Method of Study}

The peripheral blood is examined in the majority of children attending the Hospital for Sick Children, Bristol. Venous or capillary specimens so obtained from 1,455 children aged up to 16 years were examined for the presence of foetal cells by the method of Kleihauer et al. (1957). Certain precautions were taken to avoid false positive results. Thin films were processed within 24 hours (usually much less), since storage for a longer period had been found to increase the resistance of normal cells to acid lysis; fixed films undergo this change more rapidly than unfixed, and therefore fixation was followed immediately by processing. Fixation was achieved by immersing films in dry methanol for one minute in a closed container, and this was followed by rapid draining and drying in air, because when films are exposed to wet methanol, as happens during exposure on an open rack, partial resistance to lysis may develop in normal cells. [These facts were not appreciated by Fraser and Raper (1961), and they invalidate some of the conclusions drawn in that paper.] The buffer used was citric acid-disodium hydrogen phosphate, 0.15 molar, at $p \mathrm{H} 3.7$. This $p \mathrm{H}$ is slightly higher than the $p \mathrm{H}$ $(3 \cdot 4$ to $3 \cdot 6)$ used by Kleihauer et al., and was used because, while it produces complete lysis of adult red cells, it facilitates the recognition of cells containing a small amount of $\mathrm{Hb} \mathbf{F}$ (the 'intermediate cells' of Fraser and Raper, 1962). (The lower $p \mathrm{H}$ is advisable when the intention is simply to identify cells of foetal origin in adult blood, as in accidental foeto-maternal 'spill'.) At $p \mathrm{H} \mathrm{3.7}$ the amount of $\mathrm{Hb} \mathrm{F}$ as estimated visually corresponds well with the amount estimated chemically in the whole haemolysate, when account is taken of the fact that many of the visualized cells have undergone only an intermediate degree of lysis.

After 90 -second lysis at $37^{\circ} \mathrm{C}$. the films were stained with May-Grünwald for five minutes. Counts were made of foetal cells seen in (usually) 20 fields with a $1 / 12$ in. $(0 \cdot 2 \mathrm{~cm}$.) objective in a system that provided an average of 500 cells per field. Results were expressed as the number of foetal cells in 1,000 red cells. A negative result was recorded when no foetal cells were found in 50 fields.

It is to be noted that no distinction will be made in this study between fully foetal and intermediate cells, although in all the conditions mentioned below the content of $\mathrm{Hb} \mathrm{F}$ was variable from cell to cell. When cells with full retention of haemoglobin coexist in a film with all gradations to fully lysed adult cells, the decision as to which should be counted is necessarily a subjective one. Those cells were counted, and are here collectively referred to as foetal cells, which after lysis had retained enough haemoglobin for this to be recognized without doubt after staining. Thus an abnormal finding was simply that the morphological appearance of the lysed red cells corresponded with that normal for a child of considerably lower age.

\section{Results}

The Normal Disappearance of Foetal Cells. In attempting to define the normal ir.cidence of foetal cells at various ages, it has to be recognized that in the population tested there was a small number of children who, by reason of the diseases from which they suffered, might be expected to show foetal cells in excess of normal. (As an extreme example, there was one child with thalassaemia major.) In addition, it became evident that there were other children who without any obvious haematological cause produced quite large numbers of foetal cells, more, indeed, than were found in some haematological disorders. Clearly, these could not be included as members of a normal population; those with the highest counts (shown in Col. 4 of Table 1) have therefore been excluded in calculating the mean for each age. With the exclusion of 10 such children only, the mean values for the remainder are shown in Col. 5. There still remained many children with counts considerably above the mean (shown in Cols. 7 and 8), and inasmuch as some at least of these owed their high counts to a morbid state, the mean values recorded must be a little higher than would be expected in a population of healthy children. Because these high counts were found in some children, standard deviations tend to be high, and the means given in Table 1 are perhaps less informative of the general trend than are the median values given in Col. 6 . In calculating the percentage of children in whom no foetal cells at all could be found, every case has been included, and therefore the same proviso applies to this calculation (Col. 3), the 'negatives' for any age being slightly less than would be expected for normal children.

Curves derived from these results are shown in Figs. 1 and 2. Complete absence of foetal cells is first met with in a few children at the age of 6 months (Fig. 1), and the curve describes a parabolic course to reach a maximum of over $96 \%$ over the age of 5 years. It is evident that over $50 \%$ of children show some foetal cells at the age of 1 year, and that the ultimate disappearance of these cells in some children does not take place until the age of 5 years is passed.

After the age of 1 year the number of foetal cells observed is very small in most children, falling well below $0.1 \%$ before the age of 2 years. Fig. 2 shows the mean counts at different ages, and individual counts that exceeded the mean values by significant amounts. 
TABLE 1

FOETAL (F) CELLS PER 1,000 ERYTHROCYTES IN 1,455 CHILDREN OF VARIOUS AGES

\begin{tabular}{|c|c|c|c|c|c|c|c|}
\hline $\begin{array}{c}1 \\
\text { Age }\end{array}$ & $\begin{array}{c}2 \\
\text { No. } \\
\text { of } \\
\text { Children }\end{array}$ & $\begin{array}{c}3 \\
\% \\
\text { Without } \\
\text { F Cells }\end{array}$ & $\begin{array}{c}4 \\
\text { Values } \\
\text { Omitted From } \\
\text { Columns 5, 6, 7, } 8\end{array}$ & $\begin{array}{c}5 \\
\text { Average F } \\
\text { Cells per 1,000 } \\
\text { Red Cells }\end{array}$ & $\begin{array}{c}6 \\
\text { Median } \\
\text { Value }\end{array}$ & $\begin{array}{c}7 \\
\text { Counts } \\
\text { Exceeding } \\
\text { Mean }+1 \text { S.D. }\end{array}$ & $\begin{array}{c}8 \\
\text { Counts } \\
\text { Exceeding } \\
\text { Mean }+2 \text { S.D. }\end{array}$ \\
\hline$\underset{4}{\text { mths. }}$ & 8 & 0 & - & 66 & 38 & - & - \\
\hline 5 & 27 & 0 & - & $25 \cdot 8 \pm 19 \cdot 8$ & 24 & - & Cleft palate, 70 \\
\hline 6 & 27 & $11 \cdot 1$ & $\begin{array}{l}\text { Thalassaemia major, } \\
1,000\end{array}$ & $13 \cdot 9 \pm 11 \cdot 6$ & 12 & - & $\begin{array}{l}\text { Cleft palate, } 54 ; \text { congenital } \\
\text { heart, } 40\end{array}$ \\
\hline $7-8$ & 33 & $17 \cdot 6$ & Retarded, 80 & $5 \cdot 6 \pm 6 \cdot 9$ & $2 \cdot 4$ & - & Cretin, 36 ; unexplained, 20 \\
\hline $9-10$ & 26 & 27 & - & $1 \cdot 7 \pm 3 \cdot 18$ & $1 \cdot 0$ & Unexplained, 8 ; retarded, 6 & Retarded, 14 \\
\hline $11-13$ & 60 & $52 \cdot 5$ & $\begin{array}{l}\text { Cleft palate, } 100 ; \text { unex- } \\
\text { plained, } 40 ; \text { congenital } \\
\text { aplastic anaemia, } 30\end{array}$ & $1 \cdot 12 \pm 2 \cdot 96$ & 0 & Rhesus incompatibility, 7 & Multiple abnormalities, 20 \\
\hline $14-16$ & 48 & 58 & Cleft palate, 24 & $0 \cdot 98 \pm 2 \cdot 24$ & 0 & - & Cleft palate, 14 \\
\hline $17-19$ & 37 & 54 & - & $1 \cdot 30 \pm 2 \cdot 80$ & 0 & Albino, $6 \cdot 4 ;$ subthyroid, 5 & $\begin{array}{l}\text { Cleft palate, } 10 ; \text { premature, } \\
10\end{array}$ \\
\hline $20-22$ & 41 & 61 & - & $0 \cdot 86 \pm 2 \cdot 0$ & 0 & Cretin, 4 ; unexplained, 6 & Mental retardation, 7 \\
\hline $23-25$ & 75 & 70 & - & $0.8 \pm 3.08$ & 0 & $\begin{array}{l}\text { Unexplained, } 6 ; \text { congenital } \\
\text { heart, } 4\end{array}$ & Albino, 7 \\
\hline$\underset{2 t}{\text { yrs. }}$ & 25 & 72 & 一 & $0.4 \pm 0.78$ & 0 & 一 & 一 \\
\hline $2 \frac{1}{2}$ & 34 & $70 \cdot 6$ & 一 & $0 \cdot 78 \pm 1 \cdot 94$ & 0 & Unexplained, 3 & $\begin{array}{c}\text { Unexplained, } 8 ; \text { aplastic } \\
\text { anaemia, } 5\end{array}$ \\
\hline $2 \frac{3}{4}$ & 16 & - & - & - & 0 & - & - \\
\hline 3 & 52 & $73 \cdot 5$ & Dapsone anaemia, 30 & $0.33 \pm 0.91$ & 0 & Mental retardation, 3 & Acute leukaemia, 4 \\
\hline 31 & 3 & - & 一 & - & $\mathbf{0}$ & - & Mental retardation, 7 \\
\hline $3 \frac{1}{2}$ & 22 & 81 & - & $0 \cdot 2$ & 0 & - & Macrocytosis, 5 \\
\hline 39 & 12 & 一 & 一 & - & 0 & 一 & - \\
\hline 4 & 70 & $85 \cdot 7$ & 一 & $0 \cdot 25 \pm 1 \cdot 03$ & 0 & - & $\begin{array}{l}\text { Retarded, } 7 \text { : acute leukae- } \\
\text { mia, } 4 ; \text { unexplained, } 3 \cdot 4^{*}\end{array}$ \\
\hline $4 \frac{1}{2}$ & 17 & 88 & - & $0 \cdot 19$ & 0 & - & Macrocytosis, 3 \\
\hline 43 & 12 & - & - & $0 \cdot 25$ & 0 & - & Leukaemia, $2 \cdot 8$ \\
\hline $5+$ & 810 & $96 \cdot 2$ & $\begin{array}{l}\text { Spherocytosis, 40; unex- } \\
\text { plained, } 20 ; \text { congenital } \\
\text { heart, } 20\end{array}$ & $0.09 \pm 0.92$ & 0 & $\begin{array}{l}\text { Heinz body anaemia, } 2 \\
\text { unexplained, } 1 \cdot 6,1 \cdot 4 \\
1 \cdot 4^{*}, 1 \cdot 4\end{array}$ & $\begin{array}{l}\text { Unexplained, } 11^{*}, 7^{*}, 3 \cdot 4^{*} \text {, } \\
3 ; \text { leukaemia, } 5,4 ; \\
\text { macrocytosis, } 8,4,3 ; \\
\text { congenital aplastic anae- } \\
\text { mia, } 8\end{array}$ \\
\hline
\end{tabular}

* Later proved familial.

Abnormal Findings. The conditions in which foetal cells were found in numbers far exceeding the normal are shown in Cols. 4 and 8 of Table 1. Those in which the count was moderately raised are shown in Col. 7. It was surprising to find that many of the highest counts were not associated with haematological disorders, and it emerged from the results that many categories of disease had to be considered besides the anaemias, though these will be dealt with first.

Congenital Anaemias. Only nine examples were encountered, seven haemolytic and two aplastic, and these are listed in Table 2. One of the two sibs with congenital aplastic anaemia was first seen at 13 weeks, when the $\mathrm{Hb}$ was $4 \mathrm{~g}$. $/ 100 \mathrm{ml}$. Every red cell was of wholly foetal type, just as in a 35-week foetus; no red cell precursors could be found in the marrow, and red cell production had ceased at or before the 35th week of foetal life. Transfusion raised the haemoglobin, introduced adult cells, but left the foetal cells unchanged. Treatment with steroids initiated erythropoiesis in the marrow, and was followed by a gradual replacement of the foetal by more mature cells, but a normal degree of maturation had not been reached at the age of 1 year, although a reasonable haemo- 


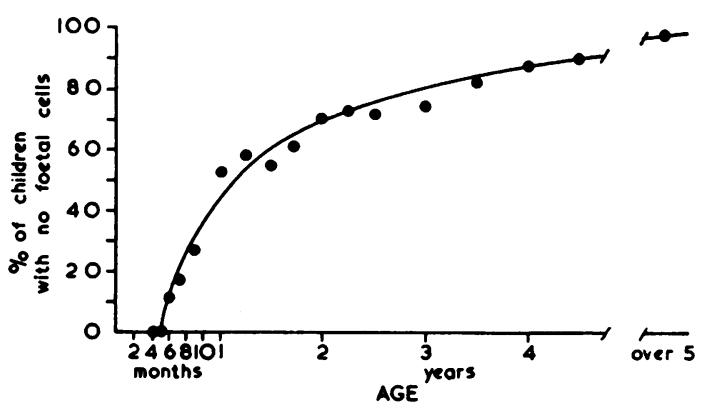

FIG. 1.-Percentage incidence of complete absence of foetal cells at various ages. (Data from Table 1, Col 3.)

globin level was maintained. The other sib had an iron deficiency anaemia at the age of 8 , but still showed foetal cells.

Among the other children the most excessive counts were in the two haemoglobinopathies represented. But one of the four children with spherocytosis showed a high count that was greatly reduced after splenectomy. In this disease the degree of foetal erythropoiesis roughly paralleled the degree of anaemia.

Acute erythroblastosis foetalis is not represented here. But 10 children who had received exchange transfusion for this disease were seen at ages up to 1 year. One showed a slight excess of foetal cells. It is notable, however, that a newborn baby with erythroblastosis actually shows a decrease in foetal cells (I. D. Fraser, 1963, personal communication). This important difference from the other congenital anaemias is explained by the increased destruction

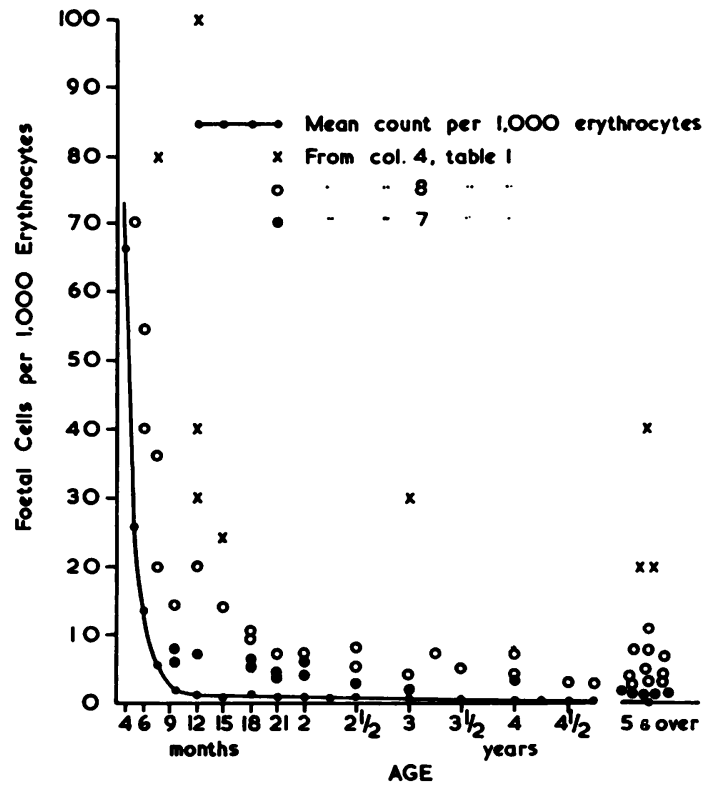

Fig. 2.-Mean foetal cell count at ages 4 months to over 5 years (continuous lines). Significantly raised counts are spotted separately.

of circulating foetal cells and their rapid replacement by cells of normal maturation for the age of the child. Although present at birth, erythroblastosis is, of course, an acquired haemolytic anaemia.

Acquired Anaemias. Two children, each aged 3 years, developed acquired haemolytic anaemia. In one the aetiology was unknown, but it was presumably of immune origin, with a positive

TABLE 2

FOETAL CELLS IN CONGENITAL ANAEMIAS

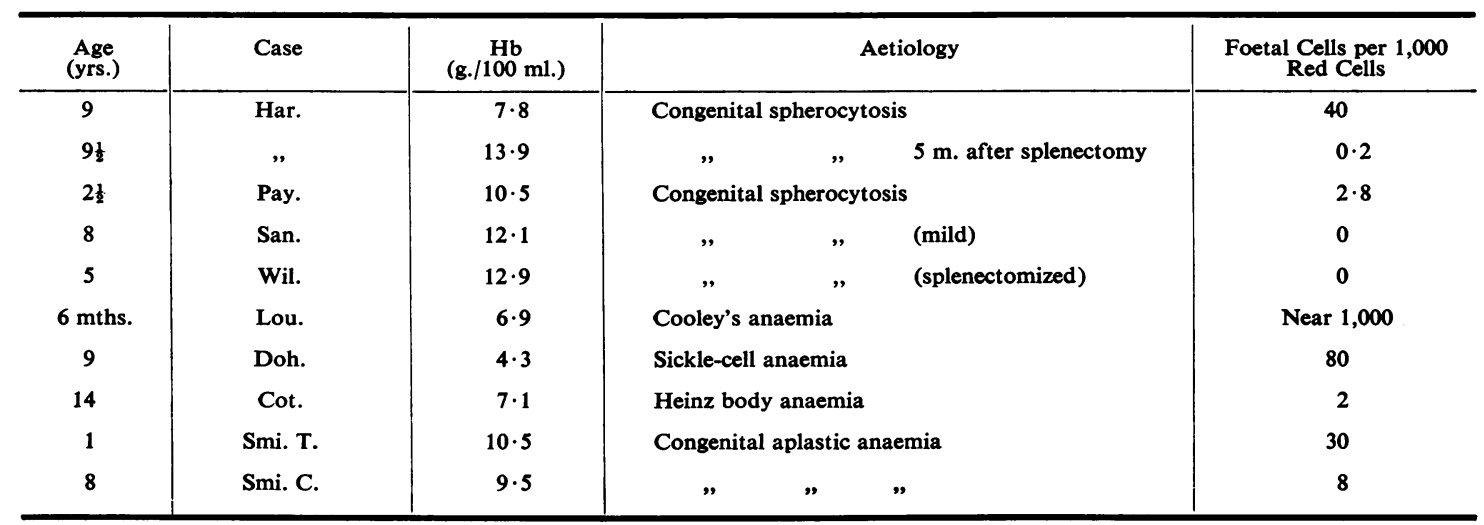


TABLE 3

FOETAL CELLS IN MACROCYTIC ANAEMIAS

\begin{tabular}{|c|c|c|c|c|c|}
\hline \multirow{2}{*}{$\begin{array}{c}\text { Age } \\
\text { (yrs.) }\end{array}$} & \multirow{2}{*}{ Case } & \multirow{2}{*}{ Aetiology } & \multirow{2}{*}{ Evidence } & \multicolumn{2}{|c|}{ Foetal Cells per 1,000 Red Cells } \\
\hline & & & & Untreated & Treated \\
\hline 12 & Ann. & Dietary & Megaloblastic marrow & 2 & 0 \\
\hline $8 \frac{1}{2}$ & Mor. & Coeliac & Macrocytosis +++ & 10 & 0 \\
\hline 7 & Jam. & Colitis, colostomy, fistulae & Macrocytosis + & 10 & - \\
\hline $4 \frac{1}{2}$ & Phi. & Folic deficiency & Megaloblastic marrow & 3 & 0 \\
\hline $3 \frac{1}{2}$ & Mil. & Chronic diarrhoea & Macrocytosis & 5 & - \\
\hline
\end{tabular}

Coombs test, and it responded to steroids; there were no foetal cells. In the other the anaemia occurred during dapsone therapy for dermatitis herpetiformis; in this case there were 30 foetal cells per 1,000 red cells. The marrow of this child was not megaloblastic, and the foetal cells disappeared when the drug was withdrawn.

There were, of course, many children with iron deficiency anaemia, of all degrees of severity, though only rarely at ages just above 6 months. In none of these children were foetal cells found, nor did they appear in a few children recovering from acute haemorrhage.

There were five children with overt macrocytic anaemia, and all showed foetal cells, though not in great numbers. These are summarized in Table 3. Another source of macrocytic anaemia, though it was only of mild degree, was amongst 48 children being treated with anti-convulsants for epilepsy. Macrocytosis was present in two of these patients, and in one there was an excess of foetal cells (two per 1,000 at age 16). However, a similar excess was seen in another epileptic child without macrocytosis, and very small numbers were seen in three other epileptics. It is suggested that the production of foetal cells in these cases (and in the case of the child exposed to dapsone) may be related to the cytotoxic effect of the drugs used. A comparison is provided by 52 adults undergoing regional methotrexate infusion for cancer; some macrocytosis was detected in five patients, and in two of these there were foetal cells (four and 0.8 per 1,000 respectively); no foetal cells were found in the remaining patients. Megaloblastic anaemias in adults produce foetal cells in numbers very similar to those seen in children. Among 20 such cases examined, foetal cells were never absent except after treatment or when the macrocytosis was very slight; they were never absent when the marrow was shown to be megaloblastic. The highest count found was 20 per 1,000 cells, the other counts being of the same order as in the children. It appears that the megaloblastic process favours the production of foetal cells to the same degree at whatever age it is acquired.

Leukaemias. There were six children with acute (probably lymphoblastic) and one with acute myeloblastic leukaemia. Their ages ranged from 3 to 7 years, and in three cases the number of foetal cells, four, four and five per 1,000 cells, was well outside the normal range. Very few foetal cells were found in one other patient, and none in the other three. These findings are very similar to what may be observed in adults.

Various Metabolic Disorders. It was conceivable that some severe metabolic defects might interfere with the synthesis of haemoglobin molecules. Those available for examination are shown in Table 4 . Albinism and subthyroidism were, in a few cases tested, the only metabolic disorders associated with some foetal erythropoiesis. The child with phenylketonuria is remarkable in that on two occasions he showed far fewer foetal cells than expected.

Congenital Dystrophies. No foetal cells were found in children over 1 year with mongolism (10 cases), meningomyelocele, hypospadias and cleft lip. One child with multiple skeletal abnormalities showed an excess of foetal cells, 20 per 1,000 at 1 year. A surprising finding was that in 15 children aged 1 to $4 \frac{1}{2}$ years with cleft palate, very

TABLE 4

FOETAL CELLS IN VARIOUS METABOLIC DISORDERS

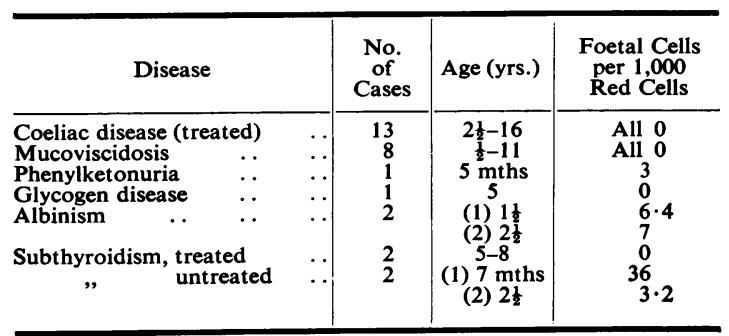


high foetal cell counts were recorded in two (Col. 4, Table 1), and high counts were found in four others (Col. 8, Table 1). No explanation is available for this.

Congenital heart disease is a special kind of dystrophy in the present connexion, because of the presence of cyanosis in some cases, causing tissue anoxia often in excess of that experienced by the foetus. It has been shown (Coghlan and Joseph, 1958) that there is no delay in the appearance of adult haemoglobin in infants so affected, and this is largely borne out by the present investigation. In 37 non-cyanotic cases of congenital heart disease, four showed an excess of foetal cells, but in only one of these did the count (seven per 1,000 cells at 2 years) fall well outside the normal range. There were eight children with cyanotic congenital heart disease; four showed foetal cells in excess, but again only one showed a great excess ( 20 per 1,000 cells at age 8). Thus there is no special tendency to produce an excess of foetal cells in congenital heart disease in general, while in the cyanotic state the effect, though it exists, is generally only a minor one.

Physical and Mental Retardation. Although certain children with mental and physical retardation were found to have an excess of foetal cells, this was not a constant finding, and the amount of foetal erythropoiesis was generally small; nor was the abnormality related to any particular syndrome.

TABLE 5

THE OCCURRENCE OF FOETAL CELLS IN FAMILIES

\begin{tabular}{l|c|c|c|c|c|}
\hline \multirow{2}{*}{ Case } & \multirow{2}{*}{$\begin{array}{c}\text { Age } \\
\text { (yrs.) }\end{array}$} & \multicolumn{3}{|c|}{ Foetal Cells per 1,000 Red Cells } \\
\cline { 3 - 6 } \cline { 3 - 5 } & Child & Father & Mother & Others \\
\hline Gi. & 4 & $3 \cdot 4$ & 5 & 0 & \\
Bi. & 7 & 11 & 8 & 0 & S Brother, 12 \\
Ro. & 9 & 7 & $1 \cdot 5$ & 0 & \\
Ly. & 11 & $3 \cdot 4$ & 0 & $1 \cdot 2$ & \\
Pa. & 12 & $1 \cdot 4$ & 0 & $0 \cdot 7$ & Sister, 0 \\
Cl. & 2 & 6 & 0 & 0 & \\
\hline
\end{tabular}

Unexplained and Familial Foetal Erythropoiesis. In all the children mentioned above, there was some possible disease association that might have explained the presence of an excess of foetal cells. But there remained a few children who were either normal or had some quite trivial complaint, in whom the finding of an excess of foetal cells could not be attributed to any disease. In eight cases the abnormal count exceeded the mean (for age) by between one and two times the standard deviation. In nine other cases the count exceeded the mean by over two times the S.D. In six of the families represented both parents were tested, with results shown in Table 5.

The inheritance of persistent foetal cell production was particularly well demonstrated in the family 'Bi'. This family has already been reported (Raper, 1962), and since that report a paternal uncle has been tested and found to carry the anomaly. Unfortunately the parents of the other children with unexplained foetal erythropoiesis could not be tested. However, it is of interest to note that in two children in whom an excess of foetal cells seemed to have a definite disease association, one a mentally retarded child, the other a child with cleft palate, both parents were tested and found negative.

The inheritance of persistent foetal erythropoiesis is thus established for some families. This phenomenon may explain some of the other positive findings that appeared not to be associated with disease. The frequency of this anomaly could not be accurately deduced from this survey, because insufficient families were examined. But since amongst 17 children with unexplained foetal erythropoiesis the families were examined in six cases, and found positive in five, the frequency may be supposed to be rather less than $1 \%$ in the population surveyed.

Another approach to this question was made by examining 100 healthy nursing candidates at the same hospital, aged about 18 to 20 . Foetal cells were found in seven. In only one of these girls, however, did the count exceed $1 \cdot 2 / 1,000$, the mean for children aged 5 and upwards. This gives a similar incidence, but it is evident from the six other counts, which were $0 \cdot 9,0 \cdot 6,0 \cdot 4,0 \cdot 2,0 \cdot 1$ and $0 \cdot 1$ foetal cells per 1,000 , that a very small number of foetal cells may appear in a rather larger proportion of young adults. The count in the first-mentioned nurse was $5 / 1,000$, and her mother showed scanty foetal cells, while her father showed none. Marti (1962) has described similar families.

\section{Discussion}

The finding of foetal cells in children with various disease states has to be viewed against the background of both the normal rate of disappearance of these cells with age, and the fact that they may persist for genetic reasons. The second question is of considerable interest, and will be discussed first.

The final stages of the 'switch-over' from foetal to adult erythropoiesis, though normally regarded as completed by the sixth to eighth month, are now shown (Figs. 1 and 2 ) to extend for a much longer period in many normal children, and to be incom- 
plete in a small proportion of children even at the age of 5 years. This may be interpreted as meaning that whatever regulates the 'switch-over', its full effect is often delayed and perhaps in some persons never achieved. Permanent arrest of this mechanism at any age would explain the presence of foetal cells in some older children and adults. The present experience suggests that this arrest occurs most often after the age of 6 months; and the fact that it occurs in several members of some families indicates hereditary transmission of a defective regulatory mechanism.

At the time that this study was begun, there had been no reports of the hereditary persistence of foetal cells. Marti's (1962) report established that there were families where some members showed a slightly raised $\mathrm{Hb} F$ in the whole haemolysate, and an increase in foetal cells. The present work agrees with this, and suggests that in nearly $1 \%$ of an English population there exists an inherited failure to achieve full conversion to adult erythropoiesis by late childhood, resulting in what appears to be fixation of red cell production at the stage normally reached at ages between 6 and 12 months. As in the normal infant, so in these older children and adults, it is quite evident that the incomplete maturation does not affect all red cell precursors, that is, some clones are normal and others are retarded in their maturation.

The effect of this suggested mechanism is quite different from that of the 'high-F' gene, which directly determines the structure of the haemoglobin formed within each normoblast, so that every red cell contains about $26 \%$ of $\mathrm{Hb} \mathrm{F}$; whereas, in all the cases considered here the distribution of $\mathrm{Hb} F$ in the red cells was irregular. The existence of these two genetic determinants of $\mathrm{Hb} F$ synthesis falls into line with the postulates of Jacob and Monod (1961). The 'high-F' gene is a 'structural' gene, directly determining the molecular organization of its product, haemoglobin. The gene (or group of genes) that determines a persistence of the early infantile pattern of erythropoiesis operates remotely from the actual synthesis of haemoglobin, and is of the nature of a 'regulator' gene. An interpretation of the present results is that the action of the regulating mechanism is often, and to varying extents, retarded; and that there exists in some families a genetic system that permanently arrests the maturation of haemoglobin synthesis before it is complete.

Just as in the case of the familial persistence of foetal erythropoiesis, so in the many diseases recorded here in which foetal cells persist or reappear, the pattern is always that of neonatal erythropoiesis.
Is it necessary to suppose that the 'regulator' has been partially inhibited? It might be that environmental factors, also operating remotely from the actual synthesis of haemoglobin, could produce the effect observed. Conceivably, when the process accompanies mental and physical retardation, or some congenital malformations, it may be due to arrest of normal maturation. The same may be true of the congenital anaemias, but unfortunately they occur in early infancy, when it is impossible to disentangle the effects of delayed maturation and disturbed erythropoiesis. However, it is fairly certain that neither anaemia in itself, nor increased marrow activity, causes a 'reversion' to foetal erythropoiesis. Thus the latter is not seen even in erythroblastosis foetalis, in haemorrhagic anaemia, or in chronic iron deficiency. But it is seen in the haemoglobinopathies, where there is certainly a derangement of haemoglobin formation and, in thalassaemia at least, a degree of disturbed erythropoiesis. The position of congenital spherocytosis is anomalous and is likely to remain so until the nature of the defect is discovered.

The macrocytic anaemias, which appear after infancy, regularly provide examples of a return to the infantile pattern of erythropoiesis; and this change is promptly reversible after effective treatment. Moreover, the extent of the change is no greater in children than it is in adults who develop macrocytic anaemia. The same is true of many cases of leukaemia. The change must, therefore, be ascribed to the altered conditions of erythropoiesis in these diseases. External factors cosld induce the change in two ways. (1) By selection, operating under the abnormal conditions, in favour of such clones of foetal-like cells as might still exist in small and inapparent numbers. (2) By imposing on some cells environmental conditions in which it is easier to produce $\gamma$-than $\beta$-polypeptide chains, perhaps by distorting the information transmitted from the 'regulator' gene. The second view is attractive, especially if we accept the view of Ingram (1961) that the $\beta$-chain is the part of the major haemoglobin molecule latest to be developed in individual maturation, and that it is the most recent addition in an evolutionary sense. The synthesis of such a 'sophisticated' component might well be more difficult, under conditions of stress, than that of the more primitive one. But it is difficult to believe that these conditions of stress would apply only to a minority of erythropoietic clones. It is almost as difficult to believe that clonal selection could bring to light the many different clones that must be predicated to explain the great variation of $\mathrm{Hb} \mathrm{F}$ content of cells that is always seen. 
A unifying hypothesis would be that in man the 'regulator' mechanism never succeeds in carrying the 'switch-over' to absolute completion; even after the age of 5 years some incompletely matured cell lines exist, which under healthy conditions produce either no $\mathrm{Hb} F$, or not enough to be detected by methods so far employed; but under certain altered environmental conditions these cells will elaborate $\gamma$ - as well as $\beta$-polypeptide chains.

Environmental factors in the marrow can hardly be offered as an explanation of the foetal type of erythropoiesis seen in the many other conditions reported here, except perhaps in the cases of cyanotic congenital heart disease and subthyroidism. The conditions in which an explanation is still demanded are bodily and mental retardation, some congenital dystrophies (especially cleft palate) and albinism. Their common feature is inborn maldevelopment, and though other forms of maldevelopment do not show foetal erythropoiesis it is at least plausible that in these particular forms the failure of development extends to the 'switch-over' process.

It is, therefore, suggested that this process, never quite complete, may be retarded by either an inherited defect in the 'regulator' gene or a more widespread failure of general development; and further that its lack of completion may be made evident under certain circumstances, of which the most important is disordered erythropoiesis.

\section{Summary}

Erythropoiesis of foetal type persists to a minor degree in most children up to the age of 1 year, and may still be detected in some children up to the age of adolescence.

Foetal erythropoiesis in several children over the age of 5 has been shown to be a familial characteristic.

Foetal erythropoiesis persists in some congenital anaemias, in malformations and in cases of arrested development. It appears regularly in macrocytic anaemias and often in leukaemia, as it does in adults.

A hypothesis is presented to explain these findings.

\section{REFERENCES}

Beaven, G. H., Ellis, M. J. and White, J. C. (1960). Studies on human foetal haemoglobin. II. Foetal haemoglobin levels in healthy children and adults and in certain haematological disorders. Brit. J. Haemat., 6, 201.

Coghlan, M. K. and Joseph, M. C. (1958). The disappearance of foetal haemoglobin in congenital cyanotic heart disease. Arch. Dis. Childh., 33, 191.

Conley, C. L. Weatherall, D. J., Richardson, S. N., Shepard, M. K. and Charache, S. (1963). Hereditary persistence of fetal hemoglobin: A study of 79 affected persons in 15 negro families in Baltimore. Blood, 21, 261.

Fraser, I. D. and Raper, A. B. (1961). Solubility of denatured haemoglobin variants in acid buffers. Nature (Lond.), 191, 355. - (1962). Observations on the change from foetal to adult erythropoiesis. Arch. Dis. Childh., 37, 289.

Ingram, V. M. (1961). Gene evolution and the haemoglobins. Nature (Lond.), 189, 704.

Jacob, F. and Monod, J. (1961). Genetic regulatory mechanisms in the synthesis of proteins. J. molec. Biol., 3, 318.

Kleihauer, E., Braun, H. and Betke, K. (1957). Demonstration von fetalem Hämoglobin in den Erythrocyten eines Blutausstrichs. Klin. Wschr., 35, 637 .

Marti, H. R. (1962). Die Vermehrung des alkaliresistenten Hämoglobins bei hämatologisch gesunden Erwachsenen. In Haemoglobin-Colloquium, Wien, 1961, ed. H. Lehmann and K. Betke, globin-Colloquium, Thieme, Stuttgart.

Raper, A. B. (1962). Persistence of haemoglobin F. Brit. med. J., 2, 1758 .

Zuelzer, W. W. and Robinson, A. R. (1961). Haemoglobin F: its significance in the genetics and evolution of haemoglobin. Nature (Lond.), 190, 237. 